Gut, 1982, 23, 181-187

\title{
Inhibition of leucocyte motility and prevention of immune-complex experimental colitis by hydroxychloroquine
}

\author{
J M RHODES,* J E McLAUGHLIN, D J C BROWN, L A NUTTALL, \\ AND D P JEWELL
}

From the Departments of Medicine and Histopathology, Royal Free Hospital, London

SUMMARY The inhibitory effects of hydroxychloroquine on leucocyte motility have been compared with those of prednisolone. It has been shown to have similar potency to prednisolone as an inhibitor of human neutrophil and monocyte motility. Hydroxychloroquine has then been compared with placebo in the prevention of an immune-complex experimental colitis in rabbits. Rectal biopsies were taken from rabbits 24 hours after initiation of colitis, coded, and graded histologically. The summated gradings for acute inflammation and goblet cell depletion had worsened more in the control rabbits (mean grade +6.7 ) than in the treated rabbits (mean grade +1.8 ) $\mathrm{P}<0.05$. There was no difference in the mononuclear cell infiltrate between the two groups. Hydroxychloroquine, which is a potent inhibitor of leucocyte motility, effectively prevents the acute inflammatory infiltrate in this experimental colitis model and therefore merits trial in human ulcerative colitis.

Prednisolone and other glucocorticoids are effective treatment for ulcerative colitis. ${ }^{12}$ One of the known effects of prednisolone is the inhibition of leucocyte chemotaxis, ${ }^{34}$ and this may be important for its therapeutic action. The 4-amino quinoline, chloroquine, has also been shown to inhibit chemotaxis of leucocytes ${ }^{3}$ as has its derivative hydroxychloroquine, ${ }^{5}$ although the latter has not previously been tested using human leucocytes. Chloroquine has also been shown to prevent the accumulation of neutrophils into experimental Arthus lesions. ${ }^{3}$ There is, however, no record of chloroquine or hydroxychloroquine having been tried as therapy for human ulcerative colitis.

An experimental colitis model has previously been described in which a modified Auer reaction ${ }^{6}$ is induced in the colon of unsensitised rabbits by intravenous injection of immune complexes after dilute formaldehyde has been instilled rectally. It has been shown that the rectal instillation of formaldehyde causes the immune-complexes to be selectively deposited in the rectal mucosa where they initiate a chronic inflammatory response. The

\footnotetext{
*Address for correspondence: Dr J M Rhodes, Department of Medicine, Queen Elizabeth Hospital, Edgbaston, Birmingham B15 2TH.

Received for publication 3 August 1981
}

formaldehyde alone causes only minimal superficial epithelial changes and does not cause a chronic inflammatory response. ${ }^{7}$ The present study was performed, firstly, to assess further the action of hydroxychloroquine on leucocyte motility and, secondly, to determine what effect hydroxychloroquine would have on the development of the immune-complex colitis. Hydroxychloroquine was tested rather than chloroquine as it is very similar pharmacologically, ${ }^{8}$ but is reported to cause macular damage less frequently. ${ }^{910}$ It would therefore be more suitable for use in patients with ulcerative colitis.

\section{Methods}

\section{CELL ISOLATION}

Twenty millilitres of venous blood (heparin $5 \mathrm{u} / \mathrm{ml}$ ) were obtained from healthy subjects, sedimented with Dextran 110 in $0.9 \%$ sodium chloride, and the supernatant centrifuged on a Ficoll-Hypaque density gradient. Neutrophils were obtained from the cell pellet (purity $>95 \%$ ) after incubation in $0.87 \%$ buffered ammonium chloride for five minutes to lyse residual erythrocytes. Mononuclear cells were obtained from the interface and centrifuged for five minutes at $150 \mathrm{~g}$ to reduce 
platelet contamination. The cell suspensions were then washed twice in glass centrifuge tubes containing Gey's medium and then resuspended in Gey's medium containing $1 \mathrm{mg} / \mathrm{ml}$ pure human serum albumin (Behringwerke). Sixty per cent or more of the resulting mononuclear cell population were positive on peroxidase staining. Haematoxylin staining showed that less than $1 \%$ of this cell population were contaminating neutrophils. This relatively high monocyte concentration is probably the result of glass adherence during the cell washing process. Any further attempts to purify the monocyte population were thought likely to affect their motility. The contaminating lymphocytes did not cause problems during measurement of chemotaxis, as migrating monocytes assume the configuration of macrophages and are then readily distinguished from lymphocytes. Lymphocytes were also found to move considerably more slowly than monocytes so never caused problems in identification of the leading front of the monocyte population. The concentration of the cell suspensions was checked using a Neubauer counting chamber and corrected to $2 \times 10^{6}$ cells $/ \mathrm{ml}$.

\section{DRUGS}

Pure preparations of prednisolone sodium phosphate and hydroxychloroquine sulphate were studied. Drug stock solutions in Gey's medium were made on the morning of test and corrected as necessary to $\mathrm{pH} 7.2$ using $0.05 \mathrm{M}$ Tris/ $\mathrm{HCl}$ buffer. The drug under test was added to both cell suspension and chemotactant so as to give the same final drug concentrations above and below the chemotaxis filter. Seven serial dilutions of each drug were studied. Both drugs were readily soluble at all concentrations tested.

CHEMOTAXIS AND RANDOM MOTILITY ASSAYS

The modified Boyden chamber assay described by Wilkinson ${ }^{12}$ was used. Three micron pore diameter filters (Millipore) were used for neutrophil chemotaxis and $8 \mu \mathrm{m}$ pore diameter for monocyte chemotaxis. Chemotaxis was directed towards casein $4 \mathrm{mg} / \mathrm{ml}$. A stock solution of casein $20 \mathrm{mg} / \mathrm{ml}$ in Gey's medium had been prepared by drop-wise addition of $1 \mathrm{M} \mathrm{NaOH}$ until pH 12 to allow dissolution of the casein followed by dropwise addition of $1 \mathrm{M}$ sodium dihydrogen phosphate buffer until $\mathrm{pH} 7 \cdot 2$. Stimulated random motility was assayed in the presence of purified human serum albumin (Behringwerke) $1 \mathrm{mg} / \mathrm{ml}$. Cells from the same population suspended in the presence and absence of test drug were tested simultaneously. Neutrophil chemotaxis and random motility were allowed to proceed for $\mathbf{4 0}$ minutes and 75 minutes respectively, monocyte chemotaxis and random motility for two hours. They took place in a humidified incubator containing $5 \% \mathrm{CO}_{2}$ at $37^{\circ} \mathrm{C}$. Each filter was then fixed, stained, and mounted and the distance moved by the leading cell front was measured in five randomly selected high power fields using the micrometer focusing adjustment of a Leitz SM microscope. Each assay was run in triplicate so that each result represents the mean of 15 observations.

\section{VIABILITY}

Cell viability was measured after incubation for one hour in the test drug solution. It was tested by both trypan blue dye exclusion and by measurement of membrane chloride gradient.

Membrane chloride gradient was measured using the method of Baur et al. ${ }^{13}$ Three $0.5 \mathrm{ml}$ aliquots of each cell suspension were taken. The first was incubated for 10 minutes at $37^{\circ} \mathrm{C}$ with $2.5 \mu \mathrm{Ci}$ ${ }^{3} \mathrm{H}_{2} \mathrm{O} / \mathrm{ml}$ and the cells then separated from the supernatant by centrifugal filtration through silicon oil. Both the cell pellet and supernatant were then counted on a Phillips PW4530 scintillation counter after addition of $10 \mathrm{ml} \mathrm{NE} 260$ scintillation cocktail (Nuclear Enterprises Limited). The intracellular water volume of the cell pellet was then calculated. The second aliquot was incubated for 10 minutes at $37^{\circ} \mathrm{C}$ with $0.5 \mu \mathrm{Ci}{ }^{14} \mathrm{C}$ inulin $/ \mathrm{ml}$ and the cell pellet separated and counted as before. The adherent water was then calculated. The third aliquot was incubated for 10 minutes at $37^{\circ} \mathrm{C}$ with $0.5 \mu \mathrm{Ci}{ }^{36} \mathrm{Cl} / \mathrm{ml}$ at $37^{\circ} \mathrm{C}$ and the cell pellet again separated and counted. The intracellular chloride concentration was then calculated making allowance for the chloride content of the adherent water.

Results were expressed as:

Percentage change in membrane chloride gradient $=$

$$
100-\left(\frac{\begin{array}{l}
\text { Chloride gradient of cells } \\
\text { incubated with drug }
\end{array}}{\begin{array}{l}
\text { Chloride gradient of cells } \\
\text { incubated without drug }
\end{array}} \times 100\right) \%
$$

EXPERIMENTAL COLITIS

Colitis was induced in rabbits using the method of Hodgson et al. ${ }^{7}$ Twelve $2 \mathrm{~kg}$ male NZW rabbits were studied. Six were given $20 \mathrm{mg} / \mathrm{kg}$ hydroxychloroquine subcutaneously daily and six were given $0.4 \mathrm{ml}$ physiological saline subcutaneously daily. A three day run-in period was allowed with the aim of achieving steady state drug levels and on the fourth day all 12 rabbits received $1 \mathrm{ml} 1 \%$ formaldehyde rectally followed two hours later by $1 \mathrm{ml}$ intravenously of human albumin (HSA)/ 
rabbit ant-HSA, complexes prepared in antigen excess. ${ }^{7}$ Rectal biopsies taken at 0,24 , and 120 hours were coded so that the histologist was unaware which rabbit they had come from and then graded from one to four for overall severity. Separate gradings were given for lamina propria, crypt and surface epithelial inflammatory infiltrates, and goblet cell depletion.

Venous blood samples were obtained from six of the rabbits (four treated and two saline controls) 20 hours after the last drug injection. These samples were assayed for hydroxychloroquine concentration using a Perkin-Elmer LC 1000 spectrofluorimeter with excitation wavelength $325 \mathrm{~nm}$ and emission wavelength $410 \mathrm{~nm}$.

\section{Results}

\section{CHEMOTAXIS FILTER ASSAY}

Dose response curves were plotted for the percentage inhibition of leucocyte motility caused by serial dilutions of each test drug. By interpolation from these curves the drug concentrations required for $50 \%$ inhibition of neutrophil chemotaxis were prednisolone $1.45 \mu \mathrm{mol} / 1$ and hydroxychloroquine $0.23 \mu \mathrm{mol} / 1$ (Figs 1 and 2). Similar drug concentrations produced inhibition of monocyte chemotaxis and inhibition of random motility of both neutrophils and monocytes (Table 1). Table 2 shows the distance moved by the leading fronts of the control leucocyte populations used for these experiments (cells from the same leucocyte population incubated in the absence of drug).

These experiments were performed on leucocytes, from a single healthy subject. To exclude an idiosyncratic response of these leucocytes, drug concentrations similar to those required for $50 \%$ inhibition of random motility were then tested on leucocytes obtained from another four healthy subjects (two male and two female). Prednisolone $(2 \mu \mathrm{mol} / \mathrm{l})$ caused $50 \%$ mean inhibition of neutrophil random motility (range 39$65 \%)$ and hydroxychloroquine $(1 \mu \mathrm{mol} / \mathrm{ml})$ caused $36 \%$ mean inhibition of neutrophil random motility (range 31-41\%).

To establish whether these drugs might simply be having a direct toxic effect neutrophils incubated for one hour in the same drug concentration were assessed for viability. Trypan blue dye exclusion was greater than $95 \%$ in each case. Cells incubated in the presence of prednisolone showed an increase in membrane chloride gradient of $14.4 \%$ and cells incubated in hydroxychloroquine showed an increase in membrane chloride gradient of only $8.6 \%$.

Another experiment was performed to determine whether the inhibitory effects of the drugs studied were reversible. Aliquots of neutrophils were incubated for one hour at $37^{\circ} \mathrm{C}$ in the presence of prednisolone $2 \mu \mathrm{mol} / \mathrm{ml}$ and hydroxychloroquine $1 \mu \mathrm{mol} / \mathrm{ml}$. Another aliquot was incubated in Gey's medium as control. After incubation half of each

Table 1 Drug concentrations causing 50\% inhibition

\begin{tabular}{lll}
\hline & $\begin{array}{l}\text { Prednisolone } \\
(\mathrm{mmol} / \mathrm{l})\end{array}$ & $\begin{array}{l}\text { Hydroxychloroquine } \\
(\mathrm{mmol} / \mathrm{l})\end{array}$ \\
\hline Neutrophil chemotaxis & 1.45 & 0.23 \\
Neutrophil random motility & 2.48 & 1.38 \\
Monocyte chemotaxis & 0.52 & 0.68 \\
Monocyte random motility & 0.68 & 0.40 \\
\hline
\end{tabular}

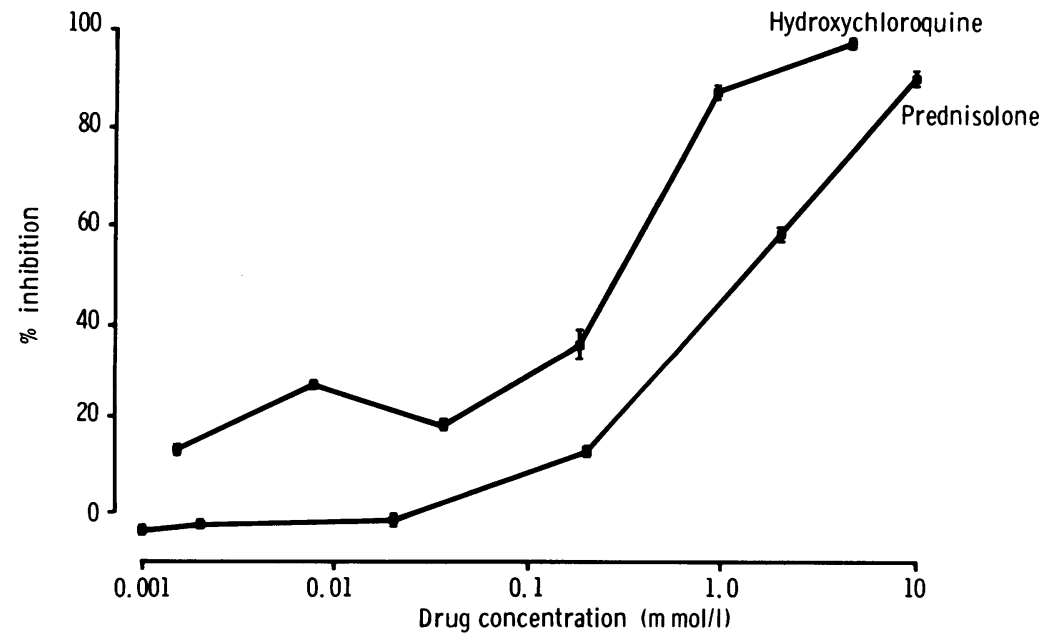

Fig. 1 Effect of serial dilutions of prednisolone and hydroxychloroquine on neutrophil chemotaxis. 


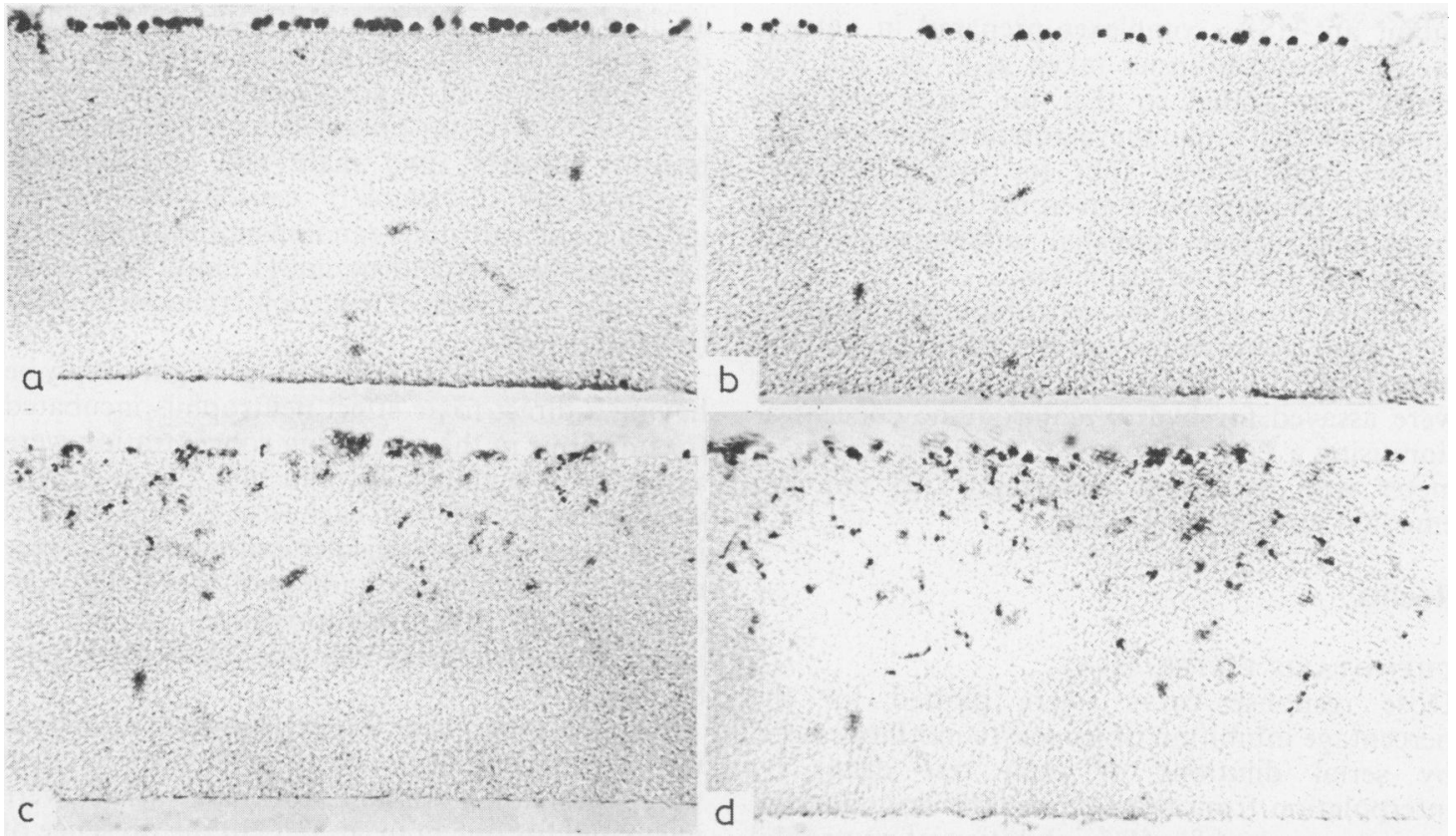

Fig. 2 Vertical cross-sections through chemotaxis filters showing effect of serial dilutions of hydroxychloroquine (a) $4.6 \mathrm{mmol} / \mathrm{l}$, (b) $0.9 \mathrm{mmol} / \mathrm{l}$, (c) $0.2 \mathrm{mmol} / \mathrm{l}$, (d) $0.04 \mathrm{mmol} / \mathrm{l}$.

Table 2 Distance moved by leading fronts of control leucocyte populations

\begin{tabular}{|c|c|c|c|}
\hline & \multirow[t]{2}{*}{ Minutes } & \multicolumn{2}{|c|}{ Distance moved ( $\mu m$, mean $\pm S D)$} \\
\hline & & Prednisolone & Hydroxychloroquine \\
\hline $\begin{array}{l}\text { Neutrophil chemotaxis } \\
\text { Neutrophil random motility } \\
\text { Monocyte chemotaxis } \\
\text { Monocyte random motility }\end{array}$ & $\begin{array}{r}40 \\
75 \\
120 \\
120\end{array}$ & $\begin{array}{r}108.4 \pm 4.1 \\
30.8 \pm 4.5 \\
100 \cdot 9 \pm 5.5 \\
54 \cdot 7 \pm 3.0\end{array}$ & $\begin{array}{r}100 \cdot 9 \pm 5 \cdot 0 \\
31 \cdot 1 \pm 4 \cdot 5 \\
123.9 \pm 3 \cdot 9 \\
41 \cdot 2 \pm 2 \cdot 1\end{array}$ \\
\hline
\end{tabular}

aliquot was washed three times in Gey's medium and all aliquots were then set up in the random motility assay. As expected the unwashed cells showed inhibition of random motility by prednisolone $2 \mu \mathrm{mol} / \mathrm{ml}(81 \%$ inhibition \pm 2.0 standard error) and hydroxychloroquine $1 \mu \mathrm{mol} / \mathrm{ml}(91 \%$ inhibition $\pm 0.93 \mathrm{SE}$ ). Cells that had been washed after incubation for one hour in prednisolone $2 \mu \mathrm{mol} / \mathrm{ml}$ were only slightly inhibited $(20 \%$ inhibition $\pm 1.29 \mathrm{SE}$ ) while cells washed after incubation for one hour in hydroxychloroquine $1 \mu \mathrm{mol} / \mathrm{ml}$ regained virtually normal motility $(5 \%$ inhibition $\pm 1.55 \mathrm{SE})$.

\section{EXPERIMENTAL COLITIS}

Having thus established that hydroxychloroquine is a potent inhibitor of leucocyte motility the next step was to determine what effect it would have on the development of the experimental colitis.

Five of the saline control rabbits showed evidence of colitis at 24 hours, while one was unchanged (mean worsening of overall grade + 1.5). One of the rabbits with features of severe colitis died at 72 hours. At 24 hours four of the six treated rabbits showed some evidence of colitis but this tended to be considerably milder (mean worsening of overall grade +0.67 ), although the difference between control and treated rabbits did not reach significance using a Chi squared test for trend in proportions ${ }^{14}\left(\chi^{2}=1.75\right)$ (Table 3$)$.

When the changes in gradings at 24 hours for acute inflammatory cell infiltrate, plasma cell infiltrate, and goblet cell depletion were summated, however, marked differences between the two 


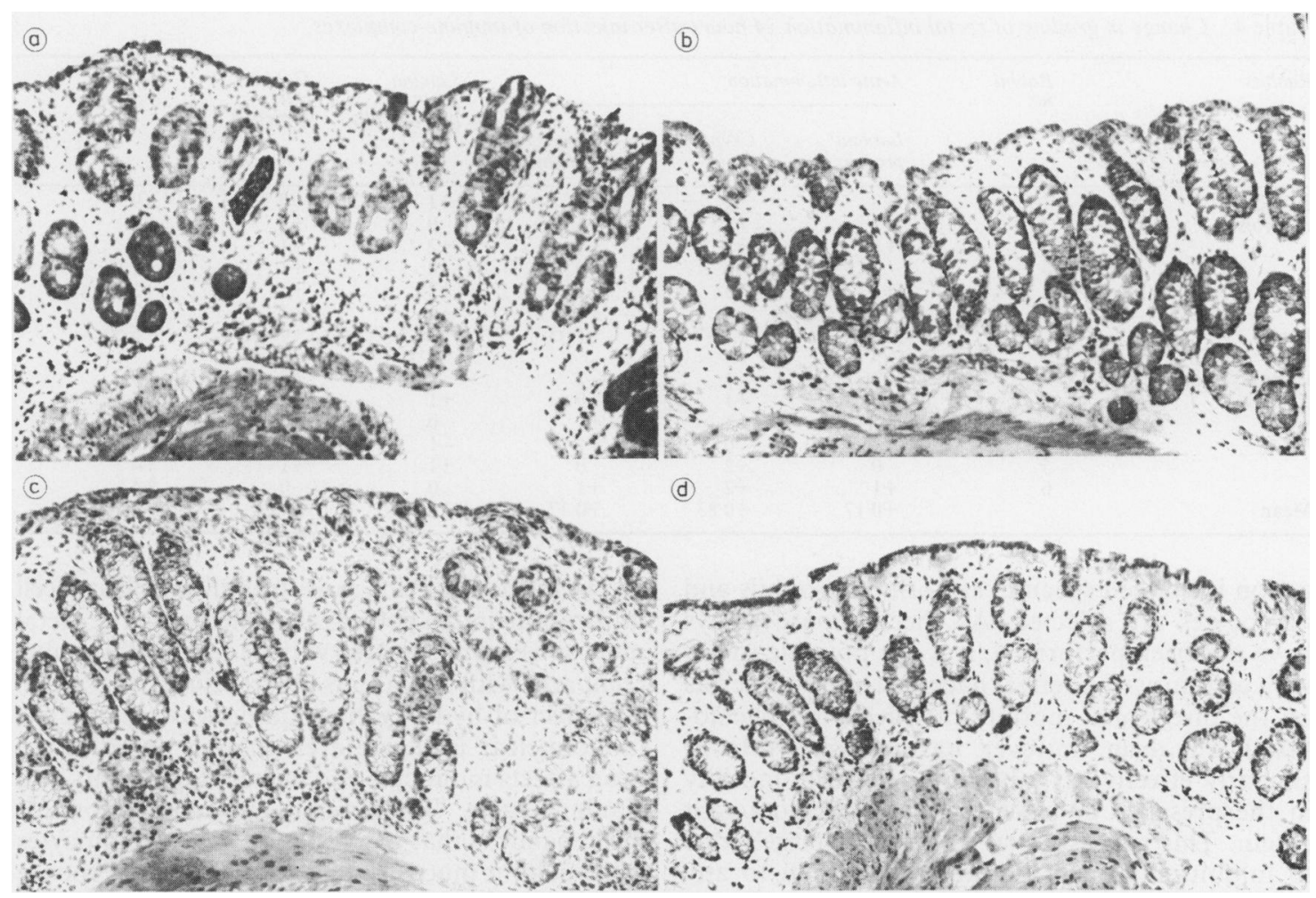

Fig. 3 Histology of rabbit rectal mucosa 24 hours after intravenous injection of immune-complexes. (a) untreated rabbit showing severe inflammation and crypt abscess formation, (b) hydroxychloroquine treated rabbit showing no inflammatory changes, (c) hydroxychloroquine treated rabbit showing lamina propria mononuclear cell infiltrate but no acute inflammation or goblet cell depletion, (d) normal rabbit rectal mucosa.

Table 3 Changes in overall grade

\begin{tabular}{lllll}
\hline Rabbits & \multicolumn{4}{l}{ Overall grades at: } \\
\cline { 2 - 5 } & 0 & $24 \mathrm{~h}$ & $120 \mathrm{~h}$ & Change at $24 \mathrm{~h}$ \\
\hline Saline & 2 & 4 & $*$ & +2 \\
control & 1 & 2 & 2 & +1 \\
& 2 & 4 & 1 & +2 \\
& 2 & 2 & 2 & 0 \\
& 1 & 4 & 2 & +3 \\
& 1 & 2 & 2 & +1 \\
Hydroxychloroquine & 2 & 1 & 3 & -1 \\
treated & 2 & 4 & 3 & +2 \\
& 2 & 2 & 2 & 0 \\
& 1 & 2 & 2 & +1 \\
& 2 & 3 & 2 & +1 \\
& 1 & 2 & 2 & +1 \\
& \multicolumn{4}{l}{ Mean change in grade at $24 \mathrm{~h}=+1 \cdot 50$} \\
& &
\end{tabular}

*Died at 72 hours.

groups were revealed (Table 4). The saline control rabbits showed considerably more acute inflammation and goblet cell depletion (mean grade $+6 \cdot 5$ ) than the hydroxychloroquine treated rabbits (mean grade +1.8$)$ and this difference was significant using the Wilcoxon rank sum test $(\mathrm{P}>0.05)$.

There was no significant difference in the lamina propria 'chronic' mononuclear cell infiltrate between the two groups (saline rabbits mean grade +0.67 , hydroxychloroquine treated rabbits mean grade +0.83 ) and this is responsible for the relatively small difference in overall grades between the two groups. By 120 hours the colitis was resolving in all surviving rabbits contrary to the findings of Hodgson et al. ${ }^{7}$

In the treated rabbits the hydroxychloroquine plasma levels 20 hours after the last injection ranged from 0.41 to $1.27 \mathrm{nmol} / 1$ (mean 0.71 $\mathrm{nmol} / \mathrm{ml}$. These are comparable with therapeutic plasma levels reported in man. ${ }^{15} 16$

\section{Discussion}

The results of the filter chamber assay demonstrate that hydroxychloroquine is at least as potent an inhibitor of leucocyte motility as prednisolone. Its 
Table 4 Change in grading of rectal inflammation 24 hours after injection of immune-complexes

\begin{tabular}{|c|c|c|c|c|c|c|c|}
\hline \multirow[t]{2}{*}{ Rabbits } & \multirow{2}{*}{$\begin{array}{l}\text { Rabbit } \\
\text { no. }\end{array}$} & \multicolumn{3}{|c|}{ Acute inflammation } & \multirow{2}{*}{$\begin{array}{l}\text { Lamina } \\
\text { propria } \\
\text { plasma cells }\end{array}$} & \multirow{2}{*}{$\begin{array}{l}\text { Goblet } \\
\text { cell } \\
\text { depletion }\end{array}$} & \multirow{2}{*}{$\begin{array}{l}\text { Total } \\
\text { score }\end{array}$} \\
\hline & & $\begin{array}{l}\text { Lamina } \\
\text { propria }\end{array}$ & Crypt & $\begin{array}{l}\text { Surface } \\
\text { epithelium }\end{array}$ & & & \\
\hline $\begin{array}{l}\text { Saline } \\
\text { controls }\end{array}$ & $\begin{array}{l}1 \\
2 \\
3 \\
4 \\
5 \\
6\end{array}$ & $\begin{array}{l}+3 \\
+1 \\
+1 \\
0 \\
+2 \\
+2 \\
+1.5\end{array}$ & $\begin{array}{l}+3 \\
+2 \\
+1 \\
0 \\
+3 \\
+1 \\
+1.67\end{array}$ & $\begin{array}{l}+2 \\
+1 \\
+1 \\
0 \\
+2 \\
+2 \\
+1 \cdot 33\end{array}$ & $\begin{array}{l}+1 \\
0 \\
+2 \\
0 \\
+3 \\
+1 \\
+1 \cdot 17\end{array}$ & $\begin{array}{l}0 \\
+1 \\
+1 \\
+1 \\
+1 \\
+1 \\
+0.83\end{array}$ & $\begin{array}{l}+9 \\
+5 \\
+6 \\
+1 \\
+11 \\
+7 \\
+6.50\end{array}$ \\
\hline $\begin{array}{l}\text { Hydroxychloroquine } \\
\text { treated }\end{array}$ & $\begin{array}{l}1 \\
2 \\
3 \\
4 \\
5 \\
6\end{array}$ & $\begin{array}{c}-2 \\
0 \\
+1 \\
+1 \\
0 \\
+1 \\
+0.17\end{array}$ & $\begin{array}{l}-1 \\
+1 \\
+1 \\
0 \\
+2 \\
+2 \\
+0.83\end{array}$ & $\begin{array}{l}-2 \\
0 \\
+1 \\
+1 \\
0 \\
+1 \\
+0.17\end{array}$ & $\begin{array}{c}0 \\
+1 \\
0 \\
-1 \\
+1 \\
0 \\
+0.17\end{array}$ & $\begin{array}{l}+0 \\
+1 \\
0 \\
+1 \\
+1 \\
0 \\
+0.50\end{array}$ & $\begin{array}{l}-5 \\
+3 \\
+3 \\
+2 \\
+4 \\
+4 \\
+1.83\end{array}$ \\
\hline
\end{tabular}

action is not cell specific, as both neutrophils and monocytes are affected. As checkerboard assays have not been performed, it is not possible to say with certainty what effect hydroxychloroquine has on the directional motility of leucocytes (chemotaxis). The drug, however, has been shown to be similarly effective at inhibiting leucocyte motility in the presence or absence of the chemotactant casein. This suggests that its effect is largely due to inhibition of cell motility rather than to any specific alteration in the ability of cells to change direction. The chloride gradient studies and the reversibility of inhibition after washing of the cells suggest that these effects are not due to any toxic effect on leucocyte membrane function.

The concentration of hydroxychloroquine required to inhibit leucocyte motility in this in vitro system is at least 100 -fold greater than that likely to occur in plasma therapeutically, and this is in agreement with the findings of Palmer and Weatherall using horse leucocytes. ${ }^{5}$ In vitro, however, the drug would be in contact with leucocytes for days rather than minutes and chloroquine and its derivatives bind to nuclei and are therefore concentrated in leucocytes. ${ }^{17}$ It therefore seems possible that therapeutic plasma concentrations of hydroxychloroquine would have an inhibitory effect on leucocyte motility. Ward, indeed, has shown that therapeutic levels of chloroquine, which has a similar inhibitory potency against chemotaxis in vitro, ${ }^{3}$ prevent accumulation of neutrophils into experimental Arthus lesions in rabbits. $^{3}$

The present study has shown that plasma levels of hydroxychloroquine comparable with therapeutic concentrations in man are sufficient to inhibit the acute inflammatory response in rabbits subjected to an immune-complex colitis. This was shown by the reduction in neutrophil and plasma cell infiltration and in goblet cell depletion in the rectal mucosa of rabbits treated with hydroxychloroquine compared with the rabbits that received only saline. No effect of hydroxychloroquine was seen on the mononuclear infiltrate even though, in vitro, the drug affects monocyte and neutrophil motility to a similar degree. One possible explanation for this discrepancy is that macrophages and lymphocytes in the colonic mucosa may have a different response to drugs from peripheral blood monocytes. Although it seems likely that the inhibition of acute inflammatory cell accumulation seen here is due to a direct effect on cell motility, hydroxychloroquine and chloroquine affect several other leucocyte functions. They bind with DNA ${ }^{17} 18$ and modify its function. 1920 They stabilise lysosomal membranes, ${ }^{21} 22$ inhibit leucocyte neutral protease, ${ }^{23}$ and reduce lymphocyte responses to mitogens. ${ }^{24} 25$

Corticosteroids are of established benefit in the management of acute attacks of ulcerative colitis but, even so, not all patients respond and surgery may still be required. The data presented here suggest that hydroxychloroquine may help to suppress acute colonic inflammation and thus be of therapeutic value. A short course of this drug carries a very low risk of side-effects, ${ }^{91026}$ and it therefore merits trial in human ulcerative colitis.

JMR is a Stanley Johnson Research Fellow. This work was supported by generous assistance from the British Digestive Foundation. Pure hydroxychloroquine was kindly supplied by SterlingWinthrop, UK, who also carried out the hydroxychloroquine drug assays. Membrane chloride gradient estimations were kindly performed by Dr T C Bartholomew. 


\section{References}

1 Truelove SC, Witts LJ. Cortisone in ulcerative colitis: final report on a therapeutic trial. Br Med J 1955; 2:1041-8.

2 Truelove SC, Jewell DP. Intensive intravenous regimen for severe attacks of ulcerative colitis. Lancet 1974; 1:1067-70.

3 Ward PA. The chemosuppression of chemotaxis. J Exp Med 1966; 124:209-26.

4 Rinehart JJ, Balcerzak SP, Sangone AL, LoBuglio AF. Effects of corticosteroids on human monocyte function. J Clin Invest 1974; 54:1337-43.

5 Palmer RMJ, Weatherall $M$. The effects of some antiinflammatory and anti-malarial drugs on the migration of horse leucocytes in vitro. Br J Pharmacol 1977; 59:472.

6 Auer J. Local autoinoculation of the sensitized organism with foreign protein as a cause of abnormal reaction. J Exp Med 1920; 32:427-44.

7 Hodgson HJF, Potter BJ, Skinner J, Jewell DP. Immune-complex mediated colitis in rabbits. Gut 1978; 19:225-32.

8 Sterling-Winthrop. Pharmacokinetics and metabolism of plaquenil and chloroquine. Internal report, 1974. No. 304/PL/74.

9 Mandel EH. The side-effects of chloroquine and hydroxychloroquine. Results of a comparative study in vivo. NY J Med 1963; 63:3111-3.

10 Shearer RV, Dubois EL. Ocular changes induced by long-term hydroxychloroquine (Plaquenil) therapy. Am $J$ Ophthalmol 1967; 64:245-52.

11 Boyum A. Isolation of mononuclear cells and granulocytes from human peripheral blood. Scand $J$ Clin Invest 1968; 21:(Suppl 97): 77-89.

12 Wilkinson PC. Chemotaxis and inflammation. Edinburgh: Churchill Livingstone 1974:170-2.

13 Baur H, Kasperek S, Pfaff E. Criteria of viability of isolated liver cells. Hoppe-Seyler's Z Physiol Chem 1975: 356:827-38.

14 Armitage P. Statistical methods in medical research Oxford: Blackwell, 1971:363-5.
15 McChesney EW, Banks WF, McAuliff JP. Laboratory studies of the 4-aminoquinoline antimalarials: II. Plasma levels of chloroquine and hydroxychloroquine in man after various oral dosage regimens. Antibiol Chemother 1962; 12:583-94.

16 Laaksonen A-L, Koskiahde V, Juva K. Dosage of antimalarial drugs for children with juvenile rheumatoid arthritis and systemic lupus erythematosus. Scand $J$ Rheumatol 1974; 3:103-8.

17 Parker FS, Irvin JL. The interaction of chloroquine with nucleic acids and nucleoproteins. J Biol Chem 1952; 199:897-909.

18 O'Brien RL. Evidence for intercalation of chloroquine into DNA. Biochim Biophys Acta 1966; 129:622-4.

19 Kurnick NB, Radcliffe IE. Reaction between DNA and quinacrine and other antimalarials. J Lab Clin Med 1962; 60:669-88.

20 Cohen SN, Yielding KL. Further studies on the mechanism of action of chloroquine: Inhibition of DNA and RNA polymerase reactions. Arthr Rheum 1964; 7:302.

21 Weissman G. Labilization and stabilization of lysosomes. Fed Proc 1964; 23:1038-44.

22 Ignarro LJ, Colombo C. Enzyme release from guineapig polymorphonuclear leucocyte lysosomes inhibited in vitro by anti-inflammatory drugs. Nature New Biol 1972; 239:155-7.

23 Kruze D, Fehr K, Menninger H, Roni A. Effect of anti-rheumatic drugs on neutral protease from human leucocyte granules. $Z$ Rheumatol 1976; 35:337-46.

24 Hurvitz D, Hirschorn K. Suppression of in vitro lymphocyte responses by chloroquine. $N$ Engl $J$ Med 1964; 273:23-6.

25 Panush RS. Effects of certain antirheumatic drugs on normal human peripheral blood lymphocytes. Inhibition of mitogen and antigen stimulated incorporation of tritiated thymidine. Arthr Rheumatol 1976; 19:907-17.

26 Rynes RI, Krohel G, Falbo A, Reinecke RD, Bartholomew LE. Ophthalmological safety of long-term hydroxychloroquine treatment. Arthr Rheumatol 1978; 21:588. 